\title{
Chapter 4 \\ Humans as agents of change in forest landscapes
}

\author{
Juliana S. Farinaci, Tatyana B. Ruseva, Catherine M. Tucker, \\ Tom P. Evans, and Mateus Batistella
}

\begin{abstract}
Forest systems play a crucial role in biogeochemical cycling and provide a variety of ecosystem services at multiple scales. Considerable progress has been made in understanding the dynamics of tropical and temperate deforestation and land-use and cover change. However, less attention has been dedicated to understanding the social and biophysical conditions under which reforestation occurs. Recent research documents the experiences of many countries that have undergone transitions from a period of high deforestation to a period of declining deforestation or even net reforestation. However, these transitions take place across a range of temporal and spatial scales. Here, we review global forest-cover trends and social processes affecting forest cover and then focus on a comparison of reforestation in
\end{abstract}

\author{
J.S. Farinaci $(\bowtie)$ \\ Núcleo de Estudos e Pesquisas Ambientais, State University of Campinas, \\ Rua dos Flamboyants, 155-Cidade Universitária Zeferino Vaz, \\ Campinas, São Paulo 13083-867, Brazil \\ e-mail: jsfarinaci@gmail.com \\ T.B. Ruseva \\ Department of Government \& Justice Studies, Appalachian State University, \\ Boone, NC, USA \\ C.M. Tucker \\ Department of Anthropology and Center for the Study of Population \\ and Environmental Change, Indiana University, Bloomington, IN, USA \\ T.P. Evans \\ Department of Geography and Vincent and Elinor Ostrom Workshop \\ in Political Theory and Policy Analysis, Indiana University, Bloomington, IN, USA \\ M. Batistella \\ Núcleo de Estudos e Pesquisas Ambientais, State University of Campinas, \\ Rua dos Flamboyants, 155-Cidade Universitária Zeferino Vaz, \\ Campinas, São Paulo 13083-867, Brazil \\ EMBRAPA Satellite Monitoring, Campinas, São Paulo, Brazil
}


the states of São Paulo, Brazil, and Indiana, United States. Both states have undergone extensive deforestation but now show forest restoration alongside continuing deforestation. Our focus on forest change at the state level permits a detailed examination of deforestation and reforestation dynamics and of the diverse social factors that underlie these changes. Among these factors, human values and attitudes appear most important.

\subsection{Introduction}

Forest systems play a crucial role in biogeochemical cycling and provide a variety of ecosystem services at multiple scales. Forested areas reduce soil erosion, are important sources of fiber and wood that are used in many economic activities, and directly support livelihoods by providing non-timber ecosystem services. Since the 1990s, considerable progress has been made in understanding the dynamics of tropical and temperate deforestation and land-use and cover change, leading to a rich understanding of the drivers of deforestation (e.g., Foster and Aber 2004, Geist and Lambin 2002, Gutman et al. 2004, Moran and Ostrom 2005, Rudel 2005). However, less attention has been dedicated to understanding the social and biophysical conditions under which reforestation occurs (e.g., Rudel and Fu 1996, Tucker and Southworth 2005). Researchers now recognize that regrowth can occur simultaneously with deforestation, but the relationship between the two is not well understood. Secondary forest regrowth and plantations can sequester significant amounts of carbon that offset at least part of the emissions from clearcutting and selective logging of forests (Nilsson and Schopfhauser 1995). The social and economic conditions under which a region transitions from deforestation to reforestation remain uncertain despite the attention paid to this topic for more than two decades (e.g., Walker 1993). The drivers of reforestation are demonstrably different from those that result in deforestation. The transition from one phase to the other represents the net impacts of a complex set of processes with connections to environmental policy and management at multiple levels of governance (Moran 2010). Such processes are affected by local, regional, and federal actors, as well as by larger-scale drivers. Interactions among actors at different levels (local, regional, federal) can produce shifts in decisionmaking that lead to a net increase in forest cover.

In several recent publications, Rudel et al. (e.g., 2005) have proposed that many countries seem to undergo a transition from a period of high deforestation to one of declining deforestation or even reforestation. These observations led to the formulation of forest transition theory (Mather 1992, Rudel 1998, Rudel et al. 2005, Walker 1993). This transition has been found in many cases, but the turnaround from deforestation to reforestation takes place across a range of temporal and spatial scales. Such a transition took place in northern Europe between 1850 and 1980, but does not appear to have happened in southern Europe. We are only beginning to understand the dynamics of social and environmental systems and the feedbacks that come into play at different stages of a forest transition or at different temporal and spatial scales. In some places, this dynamic seems to be associated with the creation 
of nonfarm employment that pulls farmers off the land (Mather 1992, Polanyi 1944), thereby inducing spontaneous recovery of forests in the abandoned fields. In other places, a scarcity of forest products has prompted restoration efforts by both governments and private landowners (Foster and Rosenzweig 2003), but other scenarios may also drive a transition.

The transition has important environmental consequences for carbon sequestration and biodiversity conservation (Foley et al. 2005). During the 1990s, $38 \%$ of the world's countries experienced increases in forest cover, but the transition began at different points in their deforestation trajectories. Some countries entered the reforestation phase with $40 \%$ of the original forest cover remaining, whereas others began at a forest cover near $0 \%$. The question of when a transition takes place has huge implications for the biodiversity of regenerating forests, among other factors. Rudel (2005) notes that the northern European transition in the twentieth century had different dynamics from the experience in Asia in the past 15 years, partly due to different governance approaches (e.g., command-and-control versus bottom-up). In parts of Asia, governments have responded strongly to a scarcity of forest products and increased flooding, resulting in aggressive reforestation campaigns. In China, this effort was centrally organized (Fang and Wang 2001, Zhang et al. 2000), whereas in India, village committees have increased the forest cover in a decentralized fashion (Foster and Rosenzweig 2003, Singh 2002).

Understanding the transition from deforestation to reforestation has major implications for mitigation of climate change, biodiversity conservation, stabilization of soils and of water supplies, and the availability of socially valuable recreation areas. The process affects both developed and developing countries. In this chapter, we briefly review the global trends and social processes that are affecting forest cover. We then focus on a comparison of reforestation in the states of São Paulo, Brazil, and Indiana, United States. Rudel et al. (2005) examined these processes at a national scale using data from the United Nations Food and Agriculture Organization, and it is mostly at this level that forest transition theory has been proposed and tested. Although national and global datasets offer the benefit of a broader spatial scale, they are often marred by inconsistencies in the quality of the data and by different definitions of "forest". To better understand the dynamics of changes in forest cover, we focused at a state level using two states for which high-quality data is available. This approach permits a more detailed examination of the forest-cover dynamics and of the diversity of social factors that underlie forest-cover change. Both states have undergone devastating deforestation but now show forest recovery alongside continuing deforestation.

\subsection{Institutional dimensions of forest-cover change}

The institutional dimensions of forest-cover change have received increasing attention in recent decades. Accumulating research indicates that institutional arrangements can permit forest destruction or promote forest conservation. Here, we define "institutions" as human-designed constraints on behavior (McGinnis 2011). 
Institutions indicate what may, must, or must not be done in a given context and encompass formal and informal rules, norms, and practices (Ostrom et al. 2002). Forest management institutions exist across many levels, from local choices for forest use to municipal, regional, and national regulations and programs. Studies of institutional arrangements have revealed certain principles and features associated with successful (sustainable) forest management and conservation, but efforts to impose standardized, "one-size-fits-all" institutional arrangements have led to many failures (Ostrom et al. 2007). In many cases, successful institutional arrangements appear to evolve in situ and adapt continuously to their specific historical, political, economic, sociocultural, and environmental contexts.

\subsubsection{Local rules and contexts}

People who live in and around forests often depend on forest resources for their livelihoods, and this dependence can provide incentives to use the resources sustainably. Researchers have identified numerous cases in which local groups have crafted forest management institutions that foster sustainability (Banana and GombyaSsembajjwe 2000, Berkes and Folke 1998, Chhatre and Agrawal 2008, Gibson et al. 2000, McCay and Acheson 1987, Ostrom 1990). Contexts associated with effective local forest management include well-defined and secure tenure rights (including communal ownership), trust and shared understanding among the people who use and manage the resource, effective monitoring and enforcement, low-cost conflict mediation, the right to create and modify at least some of the rules, and recognition of the right to self-organize, among others (Agrawal 2002, Cox et al. 2010, Dietz et al. 2003, Ostrom 1990). Perhaps most important is the finding that monitoring and enforcement are strongly correlated with forest conservation under a wide range of contexts (Gibson et al. 2005, Hayes 2006, Tucker 2010, Van Laerhoven 2010). Moreover, the ratio of group size to forest size appears to matter, at least in some contexts. At low ratios, group members find it difficult to perform adequate monitoring and maintenance, whereas higher ratios can create coordination problems (Nagendra 2007, Ostrom 2005).

Local forest management regimes present diverse rules and practices and provide evidence that community-based institutions have adaptive advantages within specific circumstances (Agrawal 2007, Gibson et al. 2000, Van Laerhoven 2010). In contrast to top-down, "one-size-fits-all" programs, local regimes may permit more flexible, locally appropriate adaptations to transformative pressures. Some local arrangements prove unsuccessful, however, and changing circumstances during the past century have transformed or eliminated many community-based management regimes. Challenges that may undermine local regimes include market demands for export crops and forest products, political strife, privatization of property rights, the capture of rights by an elite, and power struggles, as well as economic and climatic shocks (e.g., Godoy et al. 2005, Henrich 1997, Schweik et al. 2003, Verhoeven 2011). Higher-level government interventions, typically imposed 
without regard for local institutions, also tend to undermine local rules and exacerbate deforestation (Jodha 1992, McKean and Ostrom 1995). In Brazil, deforestation appears to be significantly correlated with highway construction, cattle ranching, agricultural expansion, and programs that encourage immigration (Laurance et al. 2002, Moran 1992). Yet despite continuing deforestation in the Amazon basin, studies also reveal the presence of forest regrowth (Moran et al. 1996, 2000).

\subsubsection{National regulations, programs, and top-down policies}

National laws and regulations tend to encourage top-down government involvement in nonindustrial forest management. Centralized government programs, including forest concessions, settlement programs, and land grants, have become associated with extensive deforestation (Ascher 1999, Gill et al. 2009, Malingreau and Tucker 1988, Repetto and Gillis 1988). Typically, centralized approaches eliminate or severely limit local participation in forest management, which can compromise the livelihoods of forest-dependent populations and exacerbate deforestation. Forest policies and laws designed by central governments lack a nuanced understanding of local social and ecological circumstances that shape outcomes and, if the implementation process does not appropriately consider these factors, can undermine local practices and rules that would otherwise foster sustainability (Agrawal and Chhatre 2007, Cabarle et al. 1997). In countries with high institutional capacity and policy experience (e.g., European Union policies), national policies are designed with sufficient flexibility and "wiggle room" that they offer opportunities for local variability and adaptability during their implementation (Pelli et al. 2009, Winkel and Sotirov 2011).

During the late twentieth century, the inability of top-down national policies and programs to mitigate deforestation contributed to shifts in the policy tools used to encourage conservation. In the 1980s and 1990s, community-based and comanagement efforts became popular, such as joint forest management in India (Behera 2009, Jha 2010, Murali et al. 2006). Some national governments (e.g., Bolivia, Guatemala, Peru, Tanzania) adopted decentralization initiatives as theoretical advances, and empirical examples indicated the potential advantages of devolving power over forests to the local level (Andersson et al. 2006, 2012; Persha and Blomley 2009). Although a desire to devolve costs to local levels evidently motivated decentralization of forest management, the rhetoric of decentralization emphasized the potential for local income generation, economic development, democratization, and increased social equity. The social and ecological outcomes have varied greatly (Larson and Soto 2008). Unilateral decentralization programs to promote forest conservation generally fail to account for the diversity of local and regional contexts. In some cases, decentralization has done little to affect genuine devolution of power from national to local governments. Even if decentralization programs do devolve power, they may be implemented ineffectively, sabotaged by special interest groups, or undermined by ineffective local politicians (Andersson et al. 2006, 
Ribot 1999). Nevertheless, studies of decentralization outcomes have supplied further evidence that sustainable forest management, forest regrowth, and better forest conditions are associated with monitoring and enforcement, communitybased management, secure tenure, local autonomy to make and change rules, and limited state interference (Agrawal and Chhatre 2007, Persha and Blomley 2009).

\subsubsection{Government programs and incentives for forest conservation and reforestation}

Beyond efforts to create policies that decentralize power and allow co-management, many governments have attempted to counter forest loss by direct efforts to protect forests and to expand forest cover through reforestation. Protected areas are one of the most popular tools to conserve endangered forests. In highly developed countries, National Forest and National Park systems typically became established in unpopulated areas, and forest protection became associated with the prohibition of harvesting. This model spread around the world, but encountered resistance in the less-developed countries, where indigenous and traditional populations inhabit forests and depend on them for sustenance.

Today, protected areas have a mixed record, with troubling failures and shortcomings (Brandon et al. 1998, Curran et al. 2004, Liu et al. 2001, McKibben 2006, Terborgh 1999) that contrast with examples of successful protection (Bruner et al. 2001, Hilborn et al. 2006). Where protected areas are merely "paper parks" (i.e., they exist only on paper, with no or little management on the ground), they have been plagued by implementation and enforcement problems. In some cases, national forest laws and enforcement mechanisms have been inadequate to mitigate deforestation or have created perverse incentives that exacerbated development and land-cover change. For example, ecological degradation and deforestation rates increased after the creation of Mexico's Monarch Butterfly Biosphere Reserve (Brower et al. 2002) and China's Wolong Giant Panda Reserve (Liu et al. 2001). Degradation in the Monarch Butterfly Reserve had multiple causes; the reserve undermined community institutions by occupying communally owned land, local populations resisted the loss of their traditional use rights, and the government failed to establish adequate monitoring and enforcement, giving illegal loggers ample leeway to operate (Tucker 2004). Thus, efforts to remove forest peoples or prevent local people from using forest resources can backfire when they damage preexisting institutions and enforcement mechanisms and when new enforcement mechanisms are nonexistent or ineffective (Schwartzman et al. 2000, Tucker 2004).

In less-developed nations, reforestation and forest conservation have been well documented in parts of Brazil, Nepal, India, and Mexico (Bray et al. 2005, Ghate 2004, Nagendra et al. 2008). A number of highly developed countries, including France, Switzerland, Germany, and the United States (Davis and Jacobs 2005, Zanchi et al. 2007), are experiencing reforestation trends. Although the reasons 
for reforestation differ, even within a given region, global processes and changes may lead to attitudinal and behavioral changes toward forest management (Agrawal 2005).

\subsubsection{International policies and programs}

Global concern for forest change has spurred recent international efforts to encourage collaborative arrangements and top-down institutional frameworks for forest conservation. The United Nations' 2008 initiative on Reducing Emissions from Deforestation and Forest Degradation (REDD; http://www.un-redd.org/) and the subsequent 2010 revision to include conservation and sustainable management (REDD+) have sought to engage local forest owners and communities in developing nations to reforest and protect their forests. (Hereafter, we will refer to both programs as "REDD".) Millions of dollars have been allocated, mainly by highly developed nations, to implement REDD programs in less-developed nations (Boucher et al. 2008). As in previous efforts (e.g., Clean Development Mechanism, Global Environmental Facility), the greatest burden for adopting the new regulations and changing behavior is placed upon people living in and around the world's remaining forests, who are often poor, underprivileged, and dependent on forest resources for their survival (Blom et al. 2010, Thompson et al. 2011, Young 2010). Meanwhile, people residing in highly urbanized and industrialized countries, who consume the vast majority of global energy and natural resources, bear little responsibility for changing their behavior (Ghazoul et al. 2010). Previous top-down international programs have at times exacerbated inequity and poverty, even when the stated intention was to mitigate inequity, and REDD appears to continue this trend of overlooking local priorities and socioeconomic concerns (Rosendal and Andresen 2011). Therefore, REDD projects pose a number of risks, as well as opportunities to learn from past mistakes. Lessons learned from integrated conservation and development projects and early evidence from REDD projects indicate that success is more likely when local populations are active participants and beneficiaries (Blom et al. 2010, Oestreicher et al. 2009). In many ways, REDD constitutes an emergent system of environmental governance for which the ramifications and risks have yet to be recognized (Thompson et al. 2011).

\subsection{Incentives, motivations, and household- level forest management}

The globalization of markets and ideas, modernization of economies, urbanization, and industrialization affect forest cover in myriad ways. It is therefore important to consider incentives and motivations for enhancing forest conservation and 
increasing forest cover. Although globalization is often seen as a driver of environmental degradation, it can benefit forest cover through flows of ideas, labor, capital, and commodities (Hecht et al. 2006). For example, globalization can improve forest cover through worldwide concern over the future of tropical forests and the consequent spread of conservationist ideas, migration of people from poorer countries to economically advantaged countries, and expansion of ecotourism opportunities (Lambin and Meyfroidt 2010).

Global diffusion of environmental conservation ideas may affect individual and collective behavior toward forests (Lambin and Meyfroidt 2010). These ideas can also influence governments-public policies, creation of protected areas, and incentive and enforcement programs - and companies to develop an eco-friendly image. With increasingly urbanized populations, the perception of the value of forests as sources of ecosystem services, including esthetic and recreational values, has increased relative to the perception of forests as sources of timber and farmland, leading to changes in environmental attitudes and policies (Mather 1992). The desire to use rural land for second homes, recreation, tourism, or retirement makes forests seem more attractive.

Urbanization and industrialization also relate to reforestation through the creation of off-farm jobs and a decline in rural labor opportunities (Rudel et al. 2005). The undervaluation of rural work and livelihoods, along with the cultural and economic attractiveness of urban life, stimulate rural out-migration and land abandonment (Aide and Grau 2004, Rudel 2002). Simultaneously, adoption of more productive technologies concentrates farm production in more suitable areas. Land that is less suitable for agriculture is abandoned, allowing forests to regenerate through secondary succession. However, succession may not occur if agricultural production is integrated with regional and global markets; increasing agricultural productivity may prevent farmland abandonment if the demand for agricultural products remains high and farmers can export their products to other regions. Depending on market demand, capital availability and institutional arrangements, agricultural intensification may even lead to clearing of forested areas to increase production and profits (Lambin and Meyfroidt 2010).

Modernization of economies, openness to international markets, consumers, international non-governmental organizations, and local organizations can pressure companies and governments to adopt more environmentally sound practices. Consumer demand for green-labeled products may promote sustainable forestry practices worldwide, thus encouraging conservation and reforestation. In Brazil, for example, companies interested in exporting cellulose pulp from plantations have been pushed by external markets and by local organizations to comply with environmental legislation and adopt management practices that promote conservation of native forests (Farinaci 2012). Green labeling has been used to inform consumers around the world about a company's socio-environmental practices and can remarkably influence individual behavior (Moran 2010).

However, effective monitoring of certification labels is difficult and controversial. The current proliferation of ecolabels—with more than 300 in existence (Ecolabel 
Index 2013)—makes it difficult to verify which certifications adhere to rigorous environmental standards and third-party monitoring. Corporations can invent their own private ecolabels as marketing schemes while avoiding third-party oversight (Forest Ethics 2010, Mutersbaugh 2005). More generally, monitoring remains a challenge across all levels of the commodity chain, from communities that harvest certified lumber through each link along the commodity chain in which non-certified lumber might be mixed with certified lumber. Several major organizations offer chain-of-custody certification; two of the largest (Purbawiyatna and Simula 2008) are the Forest Stewardship Council (https://ic.fsc.org/) and the Programme for Endorsement of Forest Certification (http://www.pefc.org/). However, recent efforts by certification agents and proponents to make certified goods mainstream and encourage firms to sell them have raised concerns about the vulnerability of certifications to corporate pressure (Mutersbaugh et al. 2005).

Although economic globalization can benefit forest recovery through consumer pressure and environmental discourse, it can also shift deforestation from one region to another (Lambin and Meyfroidt 2010, Meyfroidt and Lambin 2009). For instance, Mansfield et al. (2010) claimed that forest recovery catalyzed by economic growth reflects the ability of wealthy regions or countries to import forest and agricultural products and export environmental consequences. In a comparison of two biomes in Brazil, Walker (2012) concluded that forest recovery in the Atlantic Forest, where the most urbanized, populated, and industrialized Brazilian states are located, may be occurring at the expense of deforestation in the Amazon.

Globalization can benefit forest recovery through subtle mechanisms, such as changing individual attitudes, values, and choices. The dynamics of local forest management are important because they reflect the decisions of diverse and numerous forest owners. More than half of all forests in the United States are privately owned and managed by individuals, families, tribes, or the forest industry (Butler 2008, Smith et al. 2009). Management decisions are shaped by socioeconomic and ownership characteristics, market signals, policy programs, and biophysical conditions (Beach et al. 2005, Butler 2008). The practices of forest owners typically take place within defined, privately owned parcels, with limited consideration of landscape- or watershed-based impacts.

Harvests on small, family-owned lands in the United States, though episodic, are largely driven by market prices for timber, family financial needs, or the forest's health (Davis et al. 2010). Harvesting decisions, like other management choices, are among the multiple objectives landowners have for their land. These preferences often blend financial gain with an interest in the forest's non-commodity and amenity features (Best and Wayburn 2001, Knoot et al. 2010, Koontz 2001). The motivations for family ownership often focus on esthetic enjoyment, recreation, privacy, and creating a legacy for future generations (Butler 2008, Davis et al. 2010). In brief, household decisions reflect a diversity of values, attitudes, and landuse motivations (Alig 2007, Janota and Broussard 2008, Karppinen 1998).

The demographic and ownership characteristics of landowners also influence private forest management (Ross-Davis et al. 2005): age, income, education, the 
size of the landholding, length of property ownership, and residence location affect participation in government assistance programs, adoption of best management practices, and forest stewardship (Elmendorf 2003; Frimpong et al. 2006; Kilgore et al. 2007, 2008; Kindstrand et al. 2008; Koontz 2001). Recent private ownership changes show a growing number of nontraditional owners (e.g., younger, nonwhite, ex-urbanites), smaller parcels, and inadequate coordination among landowners (Best 2004, Butler 2008). Many researchers observe that landscape-wide benefits from forests may be lost as a result of increasing parcelization (i.e., division of forest tracts into multiple, smaller parcels), which typically leads to forest fragmentation and disruptions of ecological functions (Butler and Leatherberry 2004, Rickenbach et al. 2011, Vokoun et al. 2010).

Researchers further note that the sustainability of private forests demands cooperative management at multiple scales and attention to the varying spatial and temporal scales at which forests provide goods and services (Fischer and Ruseva 2010, Goldman et al. 2007, Rickenbach et al. 2011, Ruseva and Fischer 2013). Changes in forest landscapes are a function of the actions of a heterogeneous group of owners, whose individual decisions are seldom coordinated with those of others and rarely reflect the nature of forests as a public good that provides services such as clean water, air, and other amenities (MEA 2005, Ruseva and Fischer 2013). Rickenbach et al. (2011) note that "from a landscape perspective, small forest landholdings are managed in a haphazard ownership-centric way that often lacks any connection to multiscalar ecological principles". It is therefore important to closely examine the drivers and motivations that can potentially maintain forests and support forest recovery.

\subsection{Findings from a household-level analysis: two reforestation case studies}

Our research in São Paulo (Brazil) and Indiana (USA) aimed primarily to investigate the factors that motivated private landowners to plant trees, allow forests to recover, or conserve forest on their land, including interactions with government programs and social trends. Our work involved household surveys, interviews, and a timeseries analysis of land-cover change. We paid particular attention to the institutional, socioeconomic, biophysical, and legal factors that potentially influenced management decisions. Although land use is affected by decisions at many societal levels, landscape change processes often involve individual decisions, which are influenced by social and biophysical factors and by subjective values (Moran 2010, VanWey et al. 2005). We therefore analyzed motivations and land-use preferences associated with decisions by rural landowners to protect or increase forest cover on their land. We explicitly chose to examine reforestation in the contrasting contexts of a developed and a developing country to explore whether similar or different factors influenced individual decisions during forest transitions. 
Scholars have pointed out that developing countries, with Brazil as a prominent example, have not yet made the transition to increasing forest cover and that political elites continue to prevent this transition (Rudel 2005). However, research that aggregates data at a national scale, particularly for large countries such as Brazil, can miss the dynamics of change that take place at subnational scales. In fact, our initial examination of the trajectories of forest cover in São Paulo suggested similar trajectories to those in the United States-rapid deforestation then slower deforestation accompanied by gradual reforestation (Farinaci and Batistella 2012). Economic development, urbanization, and the transition in São Paulo lag a few decades behind those in Indiana, but the transition is taking place under very different political regimes, land tenure systems, and cultural and economic histories.

\subsubsection{Description of the case studies}

In São Paulo, we studied six municipalities (Campinas, Jundiaí, Monteiro Lobato, São José dos Campos, São Luiz do Paraitinga, and Ubatuba; Fig. 4.1) in the eastern part of the state, which has a humid tropical climate with annual average temperatures of 20 to $22{ }^{\circ} \mathrm{C}$. The state is highly urbanized, with $96 \%$ of the population living in urban areas, and is responsible for more than $30 \%$ of Brazil's GDP (IBGE 2011, SEADE 2011).

In São Paulo, settlement was largely led by slave owners who operated coffee estates and expanded from the state of Minas Gerais to São Paulo (and then Paraná), a process that resulted in deforestation of half of the state during the nineteenth century. Through subsequent economic cycles involving cotton, sugar cane, coffee, and oranges, deforestation continued well into the 1960s and 1970s (Dean 1995). At the beginning of the nineteenth century, São Paulo retained $81.8 \%$ of its forest cover, but by 1973 , only $8.3 \%$ of the forest cover remained, mostly on steeper terrain (Victor et al. 2005); since then, it has increased to about $17 \%$ (Instituto Florestal 2010) (Fig. 4.2). Today, nearly one-third of the counties in São Paulo are experiencing some forest regrowth for various reasons (Ehlers 2007). For example, the state government has established conservation units, and reforestation is encouraged by state fiscal incentives (Hogan et al. 2000).

The dominant natural vegetation in São Paulo is the Atlantic Forest, which is both a high-priority area for biodiversity conservation (Joly et al. 1999, Myers et al. 2000) and the most urbanized and densely populated area of Brazil (Hogan 2001). In eastern São Paulo, along the Serra do Mar mountain chain, lie the most significant remnants of the Atlantic Forest, which form a mosaic of legally protected areas (Ribeiro et al. 2009). Forest inventories conducted before the 1990s reported net decreases in São Paulo's native forests. However, more recent assessments indicate increases, especially in the eastern portion of the state. Native forest in São Paulo covers an estimated 4343718 ha, corresponding to $17 \%$ of the state's area (Instituto Florestal 2010). Plantations of exotic Eucalyptus spp. and Pinus spp. monocultures have increased from 886393 ha in 2001 to 1140113 ha in 2006, a $29 \%$ increase (Xavier and Leite 2008). 


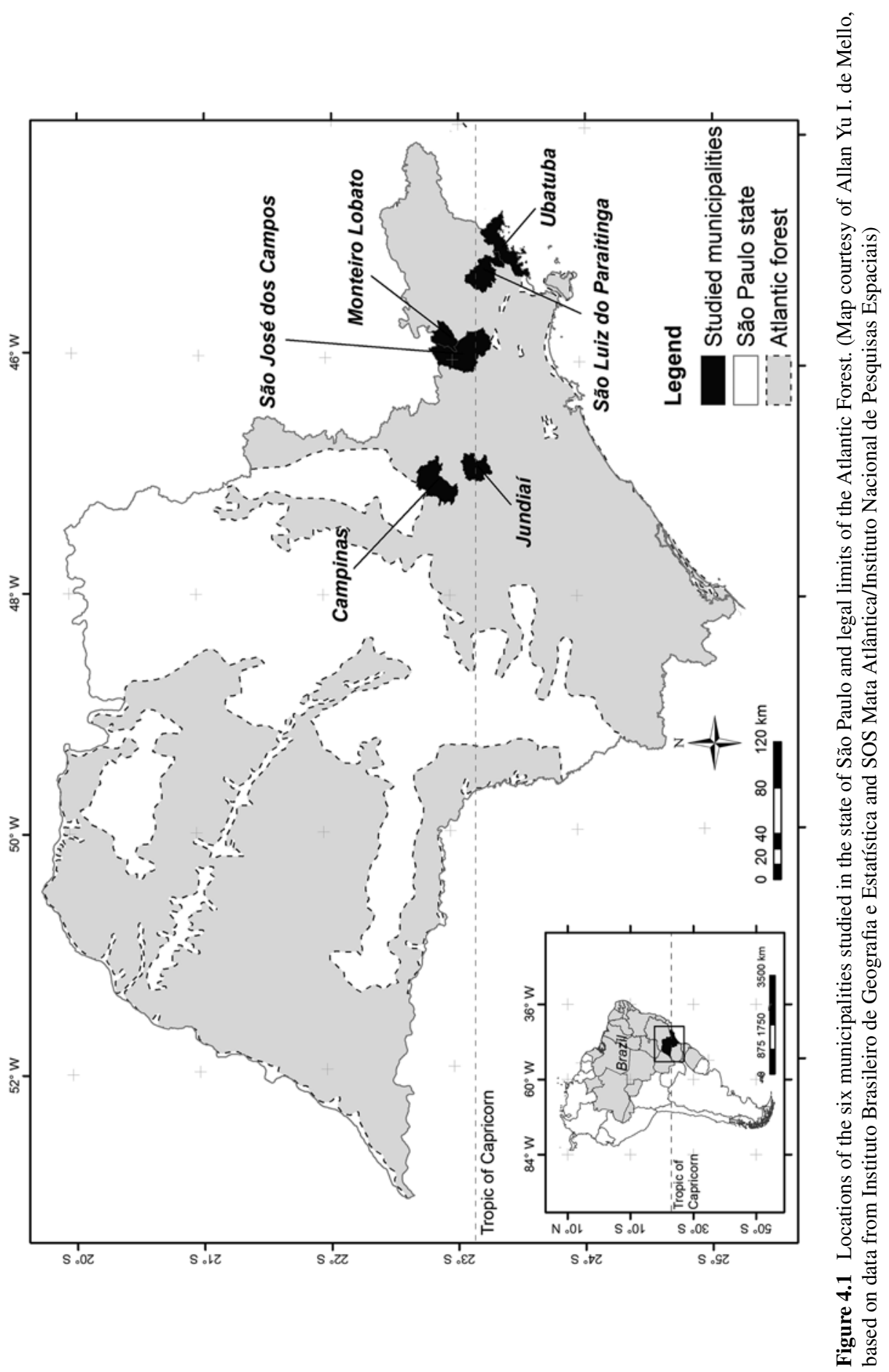




\section{São Paulo Land Cover Classification 2010}
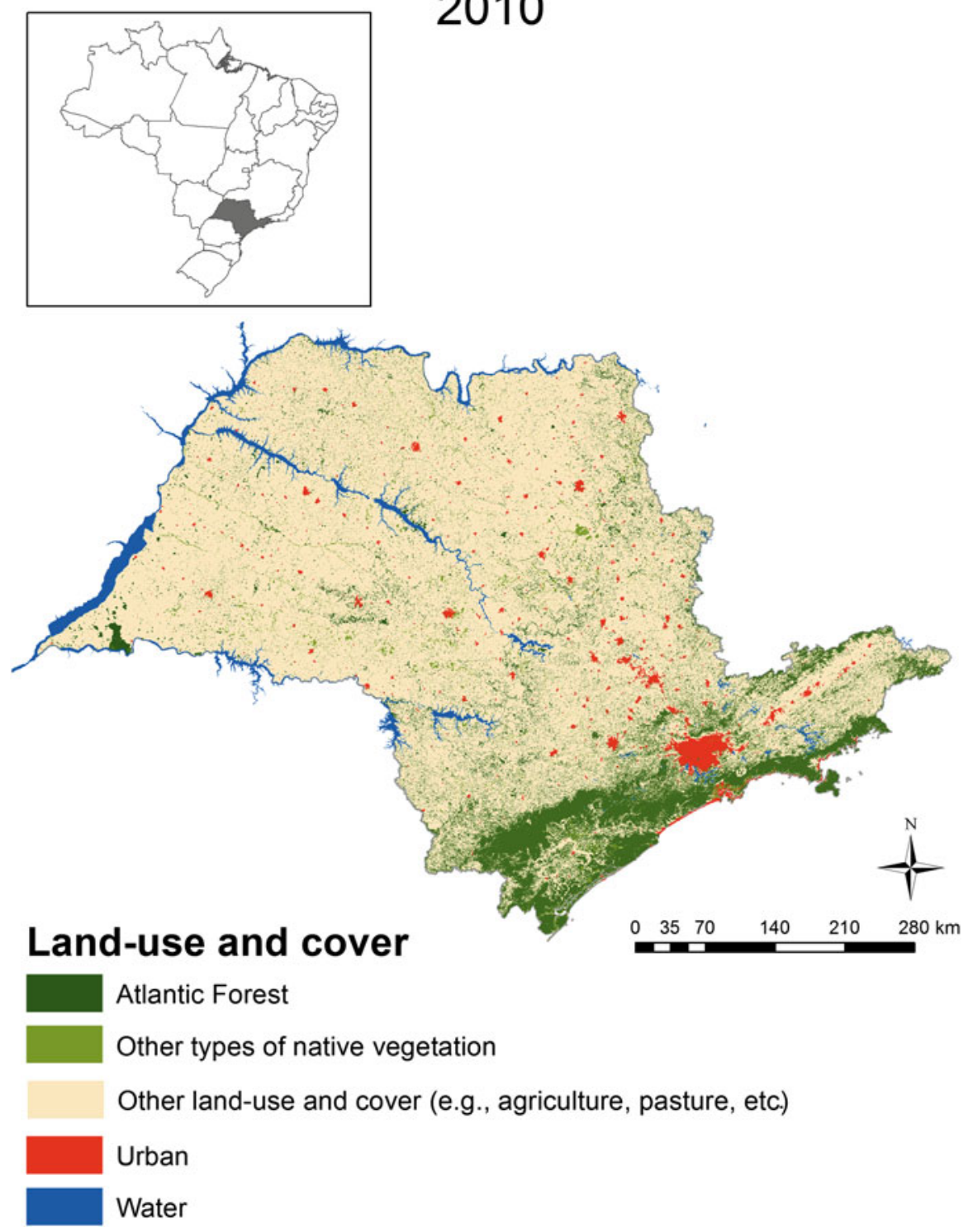

Figure 4.2 Land-use and cover classification in the state of São Paulo (2010). (Map courtesy of Allan Yu I. de Mello, based on data from Instituto Florestal and Secretaria do Meio Ambiente do Estado de São Paulo) 
Our study also included six counties in south-central Indiana: Monroe, Morgan, Decatur, Jennings, Scott, and Washington (Fig. 4.3). South-central Indiana is characterized by a mixture of low hills, forest, pasture, and agricultural crop production (mainly corn and soybeans). The mix of small-scale forests and agricultural land uses offers a range of rural amenities to a growing group of residential landowners, effectively blending the rural with the urban (Kauneckis and York 2009, Koontz 2001). In this regard, south-central Indiana is similar to other regions in the American Midwest that are experiencing residential expansion, declining agricultural land use, and peri-urban reforestation (Deller et al. 2001, Erickson et al. 2002, Kauneckis and York 2009).

Indiana provides a representative example of the forest transition in the United States. European homesteaders began to settle the region in 1810 and quickly cleared the mostly forested landscape (Madison 1986). In the late nineteenth century, Indiana had among the largest timber harvests in the United States (Parker 1997, Streightoff and Streightoff 1916). By the end of the nineteenth century, the oldgrowth forests that had covered $92 \%$ of the state prior to European settlement were almost entirely eliminated and replaced by farmland (Parker 1997). Beginning with the Great Depression and the industrial development of Chicago in the early twentieth century, rural out-migration and farm failures led to farmland abandonment and forest regrowth, so that today forest covers $20 \%$ of the state, with the largest forested areas on steeper terrain (Fig. 4.4).

Recent trends show a steady increase in Indiana's forested area (Gallion and Woodall 2010), from $6 \%$ of the state's area in the early 1900s to $20 \%$ today, with most regrowth occurring in small parcels of land owned by approximately 190000 private landowners (IDNR 2008, Woodall et al. 2005). Private individuals own $86 \%$ of all forest in Indiana, equivalent to about 1.4 million ha (IDNR 2008). The majority own parcels smaller than 40 ha (Gallion and Woodall 2010). The main income sources for most landowners include nonfarm employment, agricultural work, and forestry activities (Evans and Kelley 2004, Koontz 2001).

\subsubsection{Analytical approach}

Our findings draw on survey responses, landowner interviews, and satellite imagery for São Paulo and Indiana. Household survey instruments were pretested prior to collection of field data. Where possible, survey responses were integrated with land-use and cover change data to produce household and subregional characterizations of forest-change trajectories. In São Paulo, maps showing property boundaries did not exist, nor could they be produced during our research. This limited our ability to integrate the survey and satellite data for São Paulo. Slight variations in the data collection approaches constrain a complete comparison between São Paulo and 


\section{Decatur \\ 2 Jennings \\ 3 Monroe \\ 4 Morgan \\ 5 Scott \\ 6 Washington}

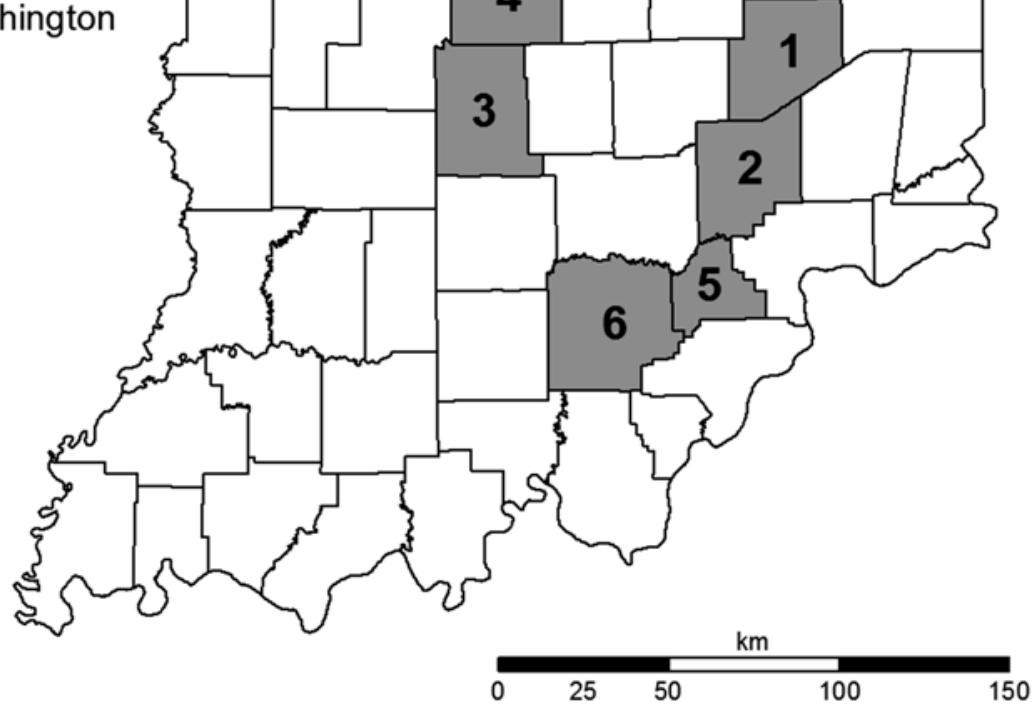

Figure 4.3 The study area in south-central Indiana, showing the six surveyed counties. (Map courtesy of the Center for the Study of Institutions, Population, and Environmental Change, 2009) 


\section{Indiana Land Cover Classification}

\section{3}
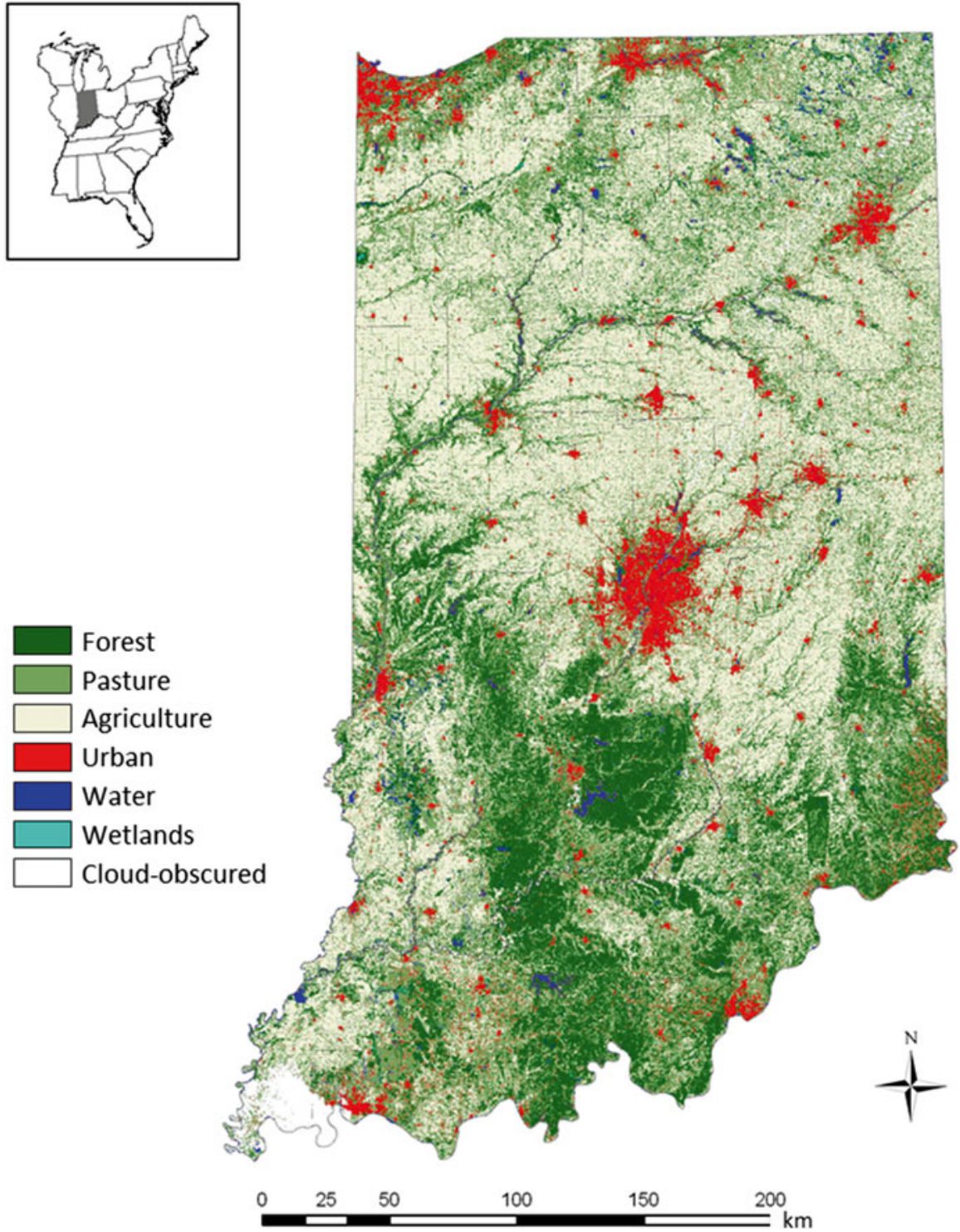

Figure 4.4 Land-use and cover classification in Indiana (2003). (Source: U.S. Department of Agriculture, National Agricultural Statistics Service)

Indiana, as well. Nevertheless, we compared the motivations for reforestation in the past 5 years using factor analysis for 15 identical survey items that measured stated motivations. We found three common motivational components or drivers (see Sect. 5). 


\subsubsection{Findings from São Paulo}

We analyzed 537 structured interviews (household surveys) from nonindustrial rural properties in six municipalities in São Paulo. We focused on reforestation between 2003 and 2008 reported by landowners. We used the cluster sampling technique (Stuart 1962) to obtain this data. We overlaid a map with the geographic locations (points) of the rural properties in each municipality, provided by the Coordenadoria de Assistência Técnica Integral of São Paulo, on satellite images and road network maps. As our main goal was to understand the motivations that lead landowners to increase forest cover, this enabled identification of clusters of properties located near forested areas, which had a greater probability of revealing forest increases. These groupings were randomized, and a team of four interviewers explored the roads and visited all the properties until at least 100 interviews had been conducted for plots larger than 2 ha in each municipality. We removed 63 surveys from the sample used for the present analysis due to missing values for specific variables, leaving 537 valid surveys for analysis.

In addition to the household survey, we conducted semi-structured interviews with landowners and rural inhabitants $(n=24)$ and with environmentalists, government managers, and tourism entrepreneurs $(n=15)$ in São Luiz do Paraitinga. These interviews were recorded and transcribed and were then analyzed using the qualitative procedures of coding and categorization; the consistency of the information was checked via triangulation (Creswell 2003).

\subsubsection{Land-use and management decisions}

Of the total area of the properties in our study in 2008, approximately $47 \%$ of the land was forested (39\% with native species and $8 \%$ with exotic species), $42 \%$ was pasture, $5 \%$ was cropland, and $2 \%$ was fallow. Landowners reported that radio, newspaper, and television were the most important sources of information for land management decisions (used by $32 \%$ of landowners), followed by friends and family (24\%), printed information (21\%), Internet resources (18\%), contracted professionals $(15 \%)$, neighbors $(14 \%)$, and government professionals $(6 \%)$. Family incomes included significant contributions from off-farm jobs $(50 \%)$, land production $(35 \%)$, and social security payments $(29 \%)$. The main professional occupation for about $35 \%$ of the landowners was related to land production (e.g., cattle breeder, farmer), $15 \%$ were retired, and the remaining half declared a diverse set of occupations. About $42 \%$ of landowners had the equivalent of a college degree or higher, but $32 \%$ had no or few years of formal education.

\subsubsection{Reforestation in São Paulo}

Classification of Landsat Thematic Mapper (TM) and ETM+ imagery indicated that between 1988 and 2007, all of the studied municipalities except Ubatuba had a net 

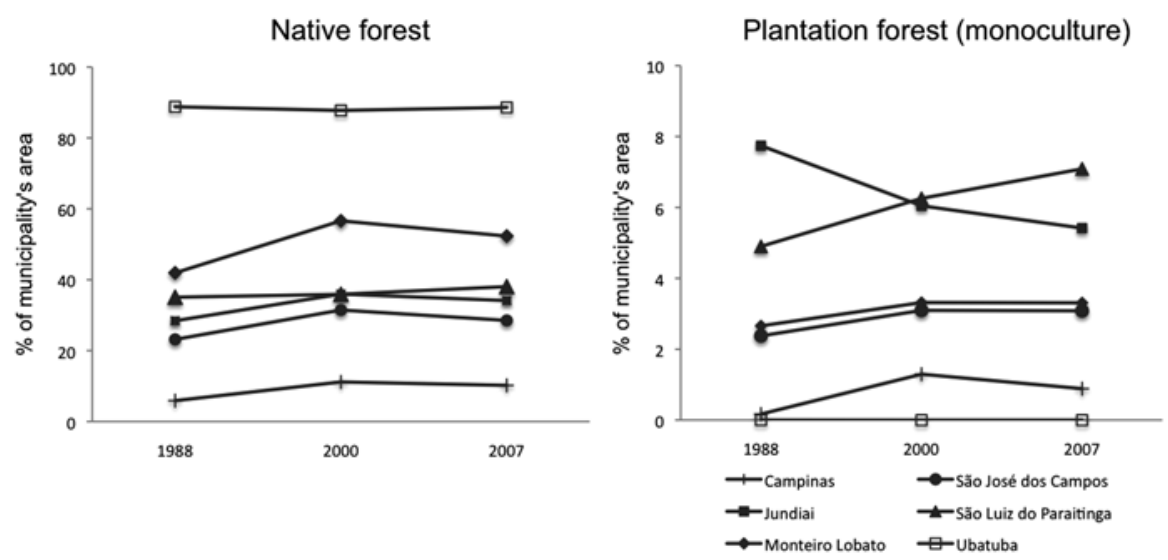

Figure 4.5 Forest cover trajectories in six municipalities in eastern São Paulo

increase in native forest cover, and all except Jundiaí (a decrease) and Ubatuba (no change) showed a net increase in monoculture forest cover (Fig. 4.5).

Of the landowners, $60 \%$ indicated that the forest cover on their properties increased during the preceding 5 years. Regeneration through secondary succession was mentioned by $78 \%$ of landowners, and $34 \%$ reported planting trees. Pasture $(48 \%)$ and riparian areas $(50 \%)$ were the most common types of land converted into forest. On the one hand, this can be explained as forest regrowth in abandoned land; on the other, it represents compliance with Brazilian legislation that mandates protection of rivers and springs by vegetation buffers.

When asked why forest cover increased in their land, most landowners reported conservation and esthetic values as important motivations. Economic incentives, wood production, and professional advice were less important or unimportant. About $41 \%$ of landowners expressed plans to reforest their land in the near future, motivated mostly by environmental conservation, esthetic values, and desired improvements in water quality. These results indicate the penetration of environmental discourse into rural zones of São Paulo, concomitant with declining land use for grazing or agricultural purposes. The property owners who increased forest cover tended to have a higher degree of formal education and to be employed in activities unrelated to land production. However, we did not detect a negative correlation between farm-based income and past reforestation, which suggests that reforestation might be compatible with productive land uses and with an economic dependence on the land. Due to a lack of information on property boundaries, we could not determine the extent of the forest increase for each property. Thus, our analyses focused on the presence or absence of reforestation as the primary outcome. Farinaci (2012) provides a detailed description of our statistical analyses.

Our results indicate that past reforestation and the intention to reforest in the near future were positively related to property size. Larger properties had higher percent- 
ages of native forest than smaller properties and were more likely to be reforested. A similar relationship was previously found in the Amazon, where deforestation intensity decreased with increasing property size (e.g., D'Antona et al. 2006, Fearnside 2005, Michalski et al. 2010). This can be explained by the higher land-use intensity on smaller farms, higher costs of maintaining cleared land on larger farms, ecological processes related to forest regeneration near existing forest areas, or a combination of these factors.

Our analysis of data from the semi-structured interviews provided a more detailed understanding of the factors that influence land-use and cover change in São Luiz do Paraitinga. Landowners generally perceived the forest area to be increasing in at least some parts of the municipality and cited a diverse set of interrelated motivating factors. The decline of dairy farming was probably the most important process leading to land abandonment and forest recovery. Modernization of the dairy farming industry, competition from other regions, and introduction of exotic grasses led to a loss of rural jobs and declining profits. Therefore, several landowners sold their land or reduced their activities to subsistence levels. In addition, declining soil fertility, a lack of investments to restore fertility, and steep slopes restricted the range of alternatives and productive land uses. Concomitantly, increases in the number of people willing to purchase land for leisure or long-term investment, legal restrictions on timber harvests, fire monitoring, and proximity to the Serra do Mar State Park were other important factors in the increased forest area in São Luiz do Paraitinga. Finally, interviewees frequently related the increased forest area to the importance of nature conservation and rural amenities (e.g., water and air quality, scenic beauty, wildlife), a finding that echoes our household survey results.

\subsubsection{Findings from Indiana}

Our results from Indiana are based on survey responses from 1939 nonindustrial private forest owners (with a $28.8 \%$ survey response rate). We constructed two samples of the landowners: one was a random sample drawn from all parcels in each of the six counties, and the second was drawn from landowners on whose land reforestation was evident from satellite imagery. We used the latter sample to ensure that we had a sufficient number of responses to characterize the attributes and preferences of landowners who had reforested their properties through tree planting or abandonment of agricultural land. We also conducted follow-up interviews with a subset of the landowners $(n=42)$. All landowners were non-urban residents who owned more than 2 ha of land. The survey responses were integrated with land-use and cover change data derived from Landsat TM satellite imagery (Evans et al. 2001, 2010; Sweeney and Evans 2012) to produce household and subregional characterizations of land-use and cover change trajectories at different spatial scales. Here, we primarily focus on the subregional rates of change to describe the social and biophysical conditions related to reforestation within the study area. 


\subsubsection{Land-use and management decisions}

Our research found a diversity of land-use preferences among Indiana landowners, which is characteristic of forest owners in developed countries (Butler 2008, Hujala et al. 2009, Karppinen 1998). At the local level, multiple forest values, ownership characteristics, and biophysical constraints are associated with forest-cover change. The landowners in our study had a mixed land-use portfolio: on average, $39 \%$ of the land was forested, $36 \%$ was cropland, $15 \%$ was mowed or used for hay production, and about $10 \%$ was grazed. Roughly $40 \%$ of landowners reported that they or their family had owned the land for more than 30 years. Length of ownership is an important measure of knowledge and forest management experience, emotional attachment to a place, and the desire to leave a legacy for future generations (Nagubadi et al. 1996, Rickenbach and Kittredge 2009). This may be changing, however, since nearly two-thirds of Indiana landowners did not expect their children to live on the land as adults- a finding that suggests a diminishing perception of land as a family legacy. Off-farm employment was a significant income contribution for more than half of the landowners. One-third had some college or technical degree training, and another third were retired.

Over two-thirds of landowners identified family and friends, along with printed information, as very or somewhat useful sources of information for making management choices. About $50 \%$ of landowners pointed to neighbors as useful sources of information, and less than half mentioned private consultants, government professionals, and the Internet. Information exchange between landowners and natural resource management professionals was limited. Most (>50\%) of the landowners were unfamiliar with existing federal and state forest assistance programs, for example. Over $89 \%$ had never participated in such programs, but a sizable proportion (35 to $43 \%$ ) had heard of the federal Conservation Reserve Program and the state's Classified Forest Program-two of the major government programs that promote forest conservation on private land.

Past management behavior, such as the decision to harvest timber, was an important indicator of land-use preferences. For example, $24 \%$ had cut trees in the past 5 years, and of those, $54 \%$ harvested timber for commercial sale and $56 \%$ cut firewood for personal use. Financial motivations were rarely a driving factor-a finding consistent with prior research (Koontz 2001). For most landowners, the decision to harvest was based on a longer time horizon and the desire to improve the forest's health. Most landowners had cut trees to remove mature trees and improve the quality of the remaining trees, improve wildlife habitat, supply wood for their own use, or achieve objectives in a management plan. Professional foresters assisted in $13 \%$ of these harvests.

In addition, changes in neighboring land were important contextual factors that affected forest land use. Residential development on nearby land was reported by more than half of the landowners. Timber harvesting was the second most commonly observed change in surrounding land and was positively correlated with landowner intentions to plant trees. This finding suggests the importance of the social context and influences of adjacent land-use practices on household decisionmaking (Knoot and Rickenbach 2011, Korhonen et al. 2012, Rickenbach et al. 2011). 

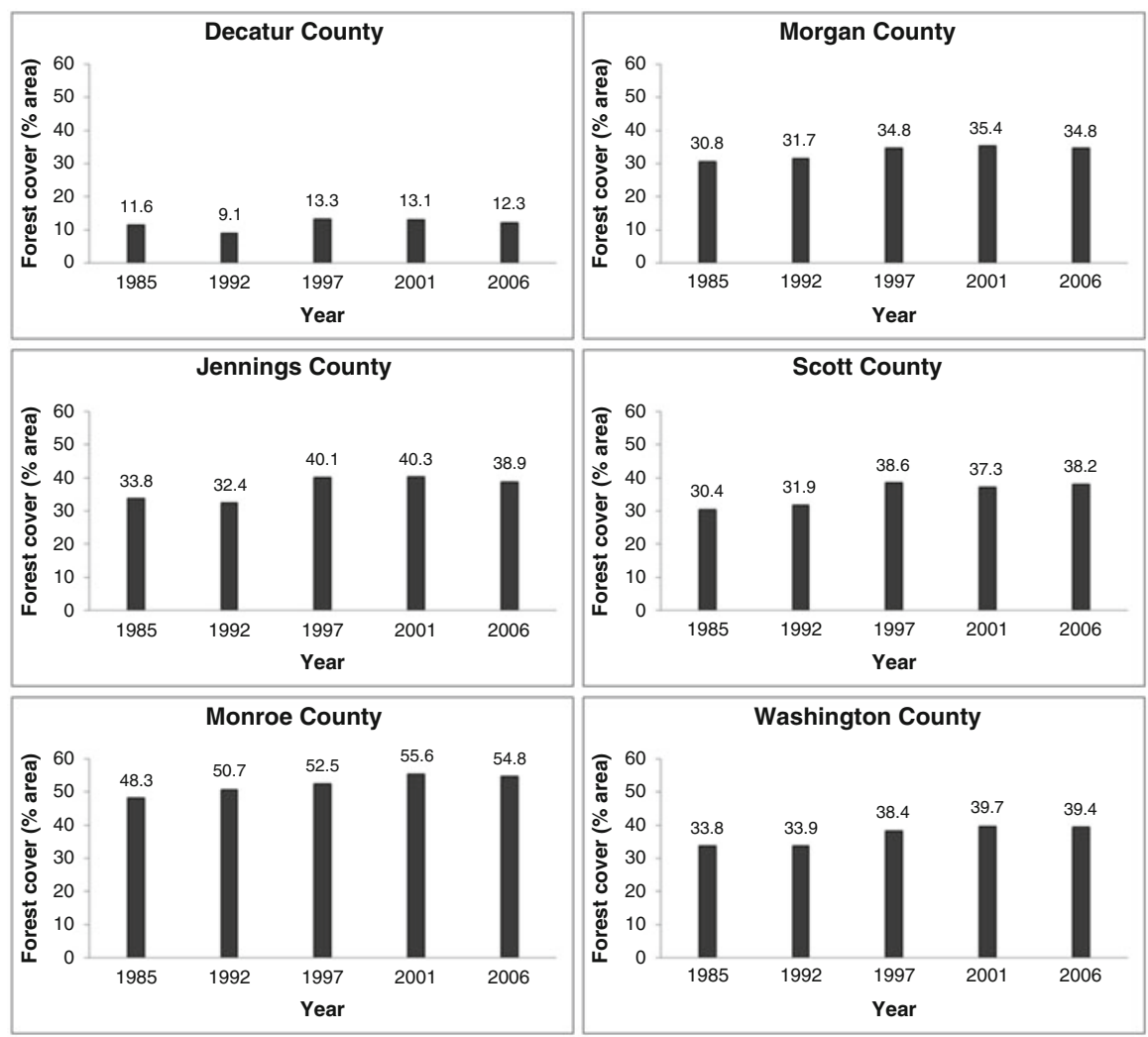

Figure 4.6 Forest cover trajectories for six counties in south-central Indiana. (Courtesy of the Center for the Study of Institutions, Population, and Environmental Change, 2009)

\subsubsection{Reforestation in Indiana}

Similar to the case in São Paulo, we examined reforestation on private land in southcentral Indiana. Analysis of cover changes using Landsat TM data revealed evidence for a modest forest-cover increase. The observed increase in forest cover area varied between $0.7 \%$ points for Decatur County and $7.8 \%$ points for Scott County from 1985 to 2006 (Fig. 4.6). In addition, among the $20 \%$ of landowners who reported an increase in the forest area in the past 5 years, $63 \%$ indicated an increase of less than 0.8 ha. Pasture was the most common type of land converted into forest. Forest regrowth mostly resulted from natural succession-i.e., leaving the land alone and letting it return to forest. A large percentage of landowners (44\%) also planted trees themselves or contracted with someone to plant trees.

Landowners were asked about their reasons for reforestation. As in São Paulo, most Indiana landowners were concerned with nature conservation and esthetics. Economic incentives, land protection, and professional advice were also important decision factors. However, we observed differences in motivations based on the size 
of the forest area increase and length of property ownership. Individuals who had owned their land for less than 10 years expressed the highest level of desire for forest conservation. Economic incentives and land protection were important among those with relatively short ownerships (5 to 10 years) and a more substantial increase in forest area (by 2.4 to 4 ha). We also found that past reforestation was significantly related to income derived from farming, timber harvesting, and land leasing, but that there was little connection between off-farm income and reported reforestation.

Most Indiana landowners $(80 \%)$ preferred their land to remain the same in the future, and about $16 \%$ expressed an interest in having more forest or a mix of forest and open space. Close to $23 \%$ of landowners intended to plant trees in the next 5 years. This represented the most common choice among a range of future land uses, such as timber harvesting, selling the land, and residential development. Most Indiana landowners are considering tree planting due to extreme weather (e.g., tornados, storms) or flooding problems, and as a result of available incentives. Government incentives, such as free seedlings, technical assistance, and direct payments, were important drivers of future land-use preferences.

We found that free seedlings and direct payments were positively associated with an intention to plant trees in the next 5 years. Expected timber price increases were particularly important for owners of larger properties. In addition, the owner's time horizon - a reflection of their age-underlay many of their intentions and preferences. For instance, we found that older owners were less likely to reforest their land. Other barriers included biophysical constraints, uncertainties related to nearby infrastructure projects, and perceptions of a lack of control over land management. In short, a combination of diverse landowner values, land-use preferences, and biophysical constraints affected local-level reforestation dynamics in south-central Indiana. The land's biophysical attributes were important factors, particularly on properties where the land was unsuitable for cultivation, on steep slopes, and in low-lying areas.

\subsubsection{Comparison of motivations for reforestation in Indiana and São Paulo}

Differences in the research methods limit the scope of comparisons between the two study areas. Nevertheless, the objectives and survey questions overlapped substantially, allowing an identification and comparison of trends. We used a merged dataset of the survey responses from Indiana and São Paulo in this part of the analysis. A factor analysis focused on 15 questions that were identical in the two studies about motivations for a forest cover increase to identify commonalities and uncover the main motivational drivers. The importance of each motivational factor was calculated as the mean response. Motivation-related questions (e.g., "I felt the land should be put into timber production", "To enhance the scenic beauty of the land", or "Tax benefits were available") were measured on a three-point ordinal scale (very important, somewhat important, not important for the forest area increase). 
Although there were some differences in the two case studies, we found substantial similarities in the landowners' stated motivations to reforest. Most notable was the overwhelming role of conservation goals among landowners in both Indiana and São Paulo. Our analysis revealed three main drivers of reforestation. The first and most important one was a conservation ethic, which reflected the desire to enhance scenic beauty, conserve nature, protect forests for future generations, and provide food and habitat for wildlife. The second important motivation was an economic incentive, including government cost-sharing, low-cost seedlings, tax incentives, and timber sales. The third motivational factor was to protect the land, in particular to improve water quality and provide a windbreak.

A conservation ethic was consistently strong and important in both Indiana and São Paulo. These motivations were slightly more pronounced in São Paulo, where $93 \%$ of the landowners cited nature conservation as very important in their reforestation decisions, whereas in Indiana, $81 \%$ identified nature conservation as important or very important.

Initially, we expected that the different legal, political, and economic contexts of São Paulo and Indiana would result in contrasting incentives for reforestation. For instance, tax breaks and economic incentives for forest conservation are more accessible in Indiana. Although landowner responses to economic incentives differed, economic incentives were secondary to conservation motivations in both Indiana and São Paulo. In Indiana, landowners often benefitted from tax breaks, but in São Paulo, few landowners stated that tax incentives were important factors in their decision to reforest. Some of these differences were attenuated when the length of property ownership was accounted for. Similarly, differences related to the desire for land protection disappeared when we controlled for the length of property ownership. The only exception was for owners with 11 to 30 years of ownership, among whom Indiana landowners showed a greater motivation than their Brazilian counterparts to use reforestation as a way to improve water quality or provide a windbreak (i.e., protect their land).

Initially, we hypothesized that the social context, in terms of the land-use practices on neighboring lands, would be an important influence on land-use choices. In both case studies, however, neighbors' activities had a minimal effect on preferences for future land use. Only $5 \%$ of Indiana landowners and less than $1 \%$ of the São Paulo landowners indicated that seeing neighbors plant trees had affected their decisions. In summary, the most important finding was the role of a conservation ethic as a key driver of household-level reforestation in both Indiana and São Paulo.

\subsection{Concluding remarks}

Our data and previous work revealed a number of factors that can be associated with increased forest cover. However, the complex causal linkages and interactions among these factors can vary among regions, making it difficult to generalize and predict future forest-cover trajectories. 
Where social and economic incentives blend with favorable policies, the relationship between people and forests can lead to reforestation. Despite this, net reforestation cannot outweigh net deforestation on a global scale. Among other factors, the increasing demand for biofuels and meat and the increasing standard of living in some countries lead to both direct and indirect adverse impacts on forests. Moreover, human influences have nonlocal impacts, as in the case when net reforestation in one country is sustained by deforestation in another.

Domestic institutions and policy approaches are essential in determining the balance. Although institutional arrangements play critical roles in promoting forest conservation or permitting forest destruction, we found no clear connections between the effects of national- and state-level forest policies and changes in forest cover in the United States and Brazil. However, our focus on states within the two countries let us examine the social and environmental processes underlying changes in forest cover in greater detail, at regional and local levels. Among the drivers, human values and attitudes appear to be the key to forest conservation and reforestation. In both Indiana and São Paulo, nature conservation and esthetics were important motivations for increasing forest cover on private land. In addition, education was positively correlated with reforestation in both Indiana and São Paulo. This mirrors the generally positive correlation between education, as a measure of socioeconomic status, and concern for the natural environment. Nevertheless, it is unclear whether education itself is a driver of forest conservation and recovery or whether a higher level of education indicates a landholder whose lifestyle depends less on land production. Whereas dependence on nonfarm income was associated with reforestation in São Paulo, reforestation in Indiana was associated with income from farm-based activities.

Overall, our study illustrates the difficulty of creating generalizations that are suitable to all countries and regions. Important human drivers are the foundation of forest change, from high-level government policy to regional and local institutions, household livelihood strategies, and individual-level behaviors. To understand the influence of people on forests, researchers must understand human institutions at all these levels and account for the diversity of social and environmental factors that exist between regions and across scales.

Acknowledgments This study was funded by the Human and Social Dynamics program of the United States National Science Foundation (grant BCS0624178), the Fundação de Amparo à Pesquisa do Estado de São Paulo (FAPESP proc. 2008/58159-7), and the Coordenação de Aperfeiçoamento de Pessoal de Nível Superior (CAPES). We thank Allan Yu I. de Mello, Scott Hetrick, and Sean P. Sweeney for remote-sensing analysis and cartographic contributions. Joanna Broderick provided valuable editorial help in refining the final version of this chapter.

\section{Literature cited}

Agrawal A (2002) Common resources and institutional sustainability. In: Ostrom E, Dietz T, Dolšak N, Stern PC, Stonich S, Weber EU (eds) The drama of the commons. National Academies, Washington, DC, pp 41-85

Agrawal A (2005) Environmentality: technologies of government and the making of subjects.

Duke University Press, Durham 
Agrawal A (2007) Forests, governance, and sustainability: common property theory and its contributions. Int J Commons 1:89-110

Agrawal A, Chhatre A (2007) State involvement and forest co-governance: evidence from the Indian Himalayas. Stud Comp Int Dev 42(1/2):67-86

Aide TM, Grau R (2004) Globalization, migration, and Latin American ecosystems. Science 305:1915-1916

Alig RJ (2007) A United States view on changes in land use and land values affecting sustainable forest management. J Sustain For 24(2):209-227

Andersson KP, Gibson CC, Lehoucq F (2006) Municipal politics and forest governance: comparative analysis of decentralization in Bolivia and Guatemala. World Dev 34(3):576-595

Andersson KP, Evans T, Gibson CC, Wright G (2012) Deforestation and decentralization: a comparative analysis of local environmental policy in three Latin American countries. Working paper. http://sobek.colorado.edu/ anderssk/Andersson_et_al_decentral_deforest.pdf. Accessed 22 Feb 2013

Ascher W (1999) Why governments waste natural resources: policy failures in developing countries. Johns Hopkins University Press, Baltimore

Banana AY, Gombya-Ssembajjwe W (2000) Successful forest management: the importance of security of tenure and rule enforcement in Ugandan forests. In: Gibson CC, McKean MA, Ostrom E (eds) People and forests: communities, institutions, and governance. MIT Press, Cambridge, pp 87-98

Beach R, Pattanayak S, Yang J, Murray B, Abt R (2005) Econometric studies of non-industrial private forest management: a review and synthesis. For Policy Econ 7(3):261-281

Behera B (2009) Explaining the performance of state-community joint forest management in India. Ecol Econ 69(1):177-185

Berkes F, Folke C (eds) (1998) Linking social and ecological systems: management practices and social mechanisms for building resilience. Cambridge University Press, Cambridge

Best C (2004) Non-governmental organizations: more owners and smaller parcels pose major stewardship challenges. J For 102(7):10-11

Best C, Wayburn LA (2001) America's private forests: status and stewardship. Island Press, Washington, DC

Blom B, Sunderland T, Murdiyarso D (2010) Getting REDD to work locally: lessons learned from integrated conservation and development projects. Environ Sci Policy 13(2):164-172

Boucher D, Movius D, Davidson C (2008) Estimating the cost and potential of reducing emissions from deforestation. Briefing \#1. Union of Concerned Scientists, Cambridge

Brandon K, Redford KH, Sanderson SE (eds) (1998) Parks in peril: people, politics and protected areas. The Nature Conservancy and Island Press, Washington

Bray DB, Merino-Perez L, Barry D (2005) The community forests of Mexico: managing for sustainable livelihoods. University of Texas Press, Austin

Brower LP, Castilleja G, Peralta A, Lopez-Garcia J, Bojorquez-Tapia L, Diaz S, Melgarejo D, Missrie M (2002) Quantitative changes in forest quality in a principal overwintering area of the Monarch butterfly in Mexico, 1971-1999. Conserv Biol 16(2):346-359

Bruner AG, Gullison RE, Rice RE, da Fonseca GAB (2001) Effectiveness of parks in protecting tropical biodiversity. Science 291(5501):125-128

Butler BJ (2008) Family forest owners of the United States, 2006. general technical report NRS27. USDA Forest Service, Northern Research Station, Newtown Square, PA

Butler BJ, Leatherberry EC (2004) America's family forest owners. J For 102(7):4-9

Cabarle B, Chapela F, Madrid S (1997) Introducción: el manejo forestal comunitario y la certificación. In: Merinol (ed) El manejo forestal comunitario en México y sus perspectivas de sustentabilidad. Centro Regional de Investigaciones Multidisciplinarias, Universidad Nacional Autónoma de México, Cuernavaca

Chhatre A, Agrawal A (2008) Forest commons and local enforcement. Proc Natl Acad Sci U S A 105(36): 13286-13291

Cox M, Arnold G, Villamayor Tomás S (2010) A review of design principles for community-based natural resource management. Ecol Soc 15(4):38. http://www.ecologyandsociety.org/vol15/ iss4/art38/. Accessed 8 May 2012 
Creswell JW (2003) Research design: qualitative, quantitative, and mixed methods approaches. Sage, Thousand Oaks

Curran LM, Trigg SN, McDonald AK, Astiani D, Hardiono YM, Siregar P, Caniago I, Kasischke E (2004) Lowland forest loss in protected areas of Indonesian Borneo. Science 303(5660): 1000-1003

D'Antona AO, VanWey LK, Hayashi CM (2006) Property size and land cover change in the Brazilian Amazon. Popul Environ 27(5-6):373-396

Davis AS, Jacobs DF (2005) Afforestation in the central hardwood forest region of the USA. In: Colombo S (comp) The thin green line: a symposium on the state-of-the-art in reforestation proceedings. Forest research information paper no. 160. Ontario Ministry of Natural Resources, Ontario Forest Research Institute, Marie, ON

Davis M, Steiner LE, Fly MJ (2010) Do you hear what I hear? Better understanding how forest management is conceptualized and practiced by private forest landowners. J For 108(6): 321-328

Dean W (1995) With broadax and firebrand: the destruction of the Brazilian Atlantic Forest. University of California Press, Berkeley

Deller SC, Tsai T-H, Marcouiller DW, English DBK (2001) The role of amenities and quality of life in rural economic growth. Am J Agric Econ 83(2):352-365

Dietz T, Ostrom E, Stern PC (2003) The struggle to govern the commons. Science 302:1907-1912

Ecolabel Index (2013) All Ecolabels. http://www.ecolabelindex.com/ecolabels/. Accessed 12 April 2013

Ehlers E (2007) Empreendedorismo e conservação ambiental no interior de São Paulo. Rev Econ Sociol Rural 45(1):185-203

Elmendorf CS (2003) Ideas, incentives, gifts, and governance: toward conservation stewardship of private land, in cultural and psychological perspective. Univ Ill Law Rev 2003:423-505

Erickson DL, Ryan RL, De Young R (2002) Woodlots in the rural landscape: landowner motivations and management attitudes in a Michigan (USA) case study. Landsc Urban Plan 58(2-4): $101-112$

Evans TP, Kelley H (2004) Multi-scale analysis of a household level agent-based model of land cover change. J Environ Manage 72(1):57-72

Evans TP, Green G, Carlson L (2001) Multi-scale analysis of landcover composition and landscape management of public and private lands in Indiana. In: Millington A, Walsh S, Osborne P (eds) GIS and remote sensing applications in biogeography and ecology. Kluwer, Boston, pp 271-287

Evans TP, Donnelly S, Sweeney S (2010) Threats to the forest transition in the Midwest United States. In: Nagendra H, Southworth J (eds) Reforesting landscapes: linking pattern and process. Springer, Dordrecht, pp 175-203

Fang JY, Wang ZM (2001) Forest biomass estimation at regional and global levels, with special reference to China's forest biomass. Ecol Res 16(3):587-592

Farinaci JS (2012). The new forests of São Paulo State: a multiscale study using the forest transition theory perspective. PhD dissertation, Environmental Studies Center, University of Campinas, Campinas, Brazil. http://www.bibliotecadigital.unicamp.br/document/?code=000857552 (in Portuguese)

Farinaci JS, Batistella M (2012) Variation on native vegetation cover in São Paulo: an overview of current knowledge. Rev Árvore 36(4):695-705

Fearnside PM (2005) Deforestation in Brazilian Amazonia: history, rates and consequences. Conserv Biol 19(3):680-688

Fischer BC, Ruseva T (2010) What is happening in and outside America's private woodlands? (Invited Response to Coufal et al. 2010). J For 108(6):304-306

Foley JA, DeFries R, Asner GP, Barford C, Bonan G, Carpenter SR, Chapin FS, Coe MT, Daily GC, Gibbs HK, Helkowski JH, Holloway T, Howard EA, Kucharik CJ, Monfreda C, Patz JA, Prentice IC, Ramankutty N, Snyder PK (2005) Global consequences of land use. Science 309(5734):570-574

Forest Ethics (2010) SFI: certified greenwash: inside the sustainable forestry initiative's deceptive eco-label. http://forestethics.org/downloads/SFI-Certified-Greenwash_Report_ForestEthics.pdf. Accessed 6 May 2012 
Foster DR, Aber JD (eds) (2004) Forests in time: the environmental consequences of 1000 years of change in New England. Yale University Press, New Haven

Foster AD, Rosenzweig MR (2003) Economic growth and the rise of forests. Q J Econ 118(2):601-637

Frimpong E, Ross-Davis A, Lee J, Broussard S (2006) Biophysical and socioeconomic factors explaining the extent of forest cover on private ownerships in a Midwestern (USA) agrarian landscape. Landsc Ecol 21(5):763-776

Gallion J, Woodall C (2010) The sustainability of Indiana's forest resources. Division of Forestry, Indiana Department of Natural Resources, Brownstown. http://www.in.gov/dnr/forestry/files/ fo-SIFR(lowres).pdf. Accessed 8 May 2012

Geist HJ, Lambin EF (2002) Proximate causes and underlying driving forces of tropical deforestation. BioScience 52(2):143-150

Ghate R (2004) Uncommons in the commons: community initiated forest resource management. Concept Publishing, New Delhi

Ghazoul J, Butler RA, Mateo-Vega J, Koh LP (2010) REDD: reckoning of environment and development implications. Trends Ecol Evol 25:396-402

Gibson CC, McKean MA, Ostrom E (eds) (2000) People and forests: communities, institutions and governance. MIT Press, Cambridge

Gibson CC, Williams JT, Ostrom E (2005) Local enforcement and better forests. World Dev 33(2):273-284

Gill SK, Ross WH, Panya O (2009) Moving beyond rhetoric: the need for participatory forest management with the Jakun of south-east Pahang, Malaysia. J Trop For Sci 21(2):123-138

Godoy R, Reyes-Garcia V, Byron E, Leonard WR, Vadez V (2005) The effect of market economies on the well-being of indigenous peoples and on their use of renewable natural resources. Annu Rev Anthropol 34(1):121-138

Goldman RI, Thompson BH, Daily GC (2007) Institutional incentives for managing the landscape: inducing cooperation for the production of ecosystem services. Ecol Econ 64:333-343

Gutman G, Janetos A, Justice C, Moran E, Mustard J, Rindfuss R, Skole D, Turner BL II (eds) (2004) Land change science: observing, monitoring, and understanding trajectories of change on the Earth's surface. Kluwer, New York

Hayes T (2006) Parks, people and forest protection: an institutional assessment of effectiveness of protected areas. World Dev 34(12):2064-2075

Hecht SB, Kandel S, Gomes I, Cuellar N, Rosa H (2006) Globalization, forest resurgence, and environmental politics in El Salvador. World Dev 34(2):308-323

Henrich J (1997) Market incorporation, agricultural change, and sustainability among the Machiguenga Indians of the Peruvian Amazon. Hum Ecol 25(2):319-351

Hilborn R, Arcese P, Borner M, Hando J, Hopcraft G, Loibooki M, Mduma S, Sinclair ARE (2006) Effective enforcement in a conservation area. Science 314(5803):1266

Hogan DJ (2001) Demographic dynamics and environmental change in Brazil. Ambiente e Sociedade 9:1-30

Hogan DJ, do Carmo RL, Tavolaro SBF, Pinto LACG, Rodrigues IA, Alves HPF, Raquel F (2000) Um breve perfil ambiental do estado de São Paulo. In: Hogan DJ, Cunha JM, Baeninger R, do Carmo RL (eds) Migração e ambiente em São Paulo: aspectos relevantes da dinâmica recente. Núcleo de Estudos de População, University of Campinas, Campinas, Brazil, pp 275-381

Hujala T, Tikkanen J, Hanninen H, Virkkula O (2009) Family forest owners' perceptions of decision support. Scand J For Res 24:448-460

IBGE (2011) Censo demográfico 2010. Instituto Brasileiro de Geografia e Estatística. http://www. ibge.gov.br/estadosat/temas.php?sigla=sp\&tema=sinopse_censodemog2010. Accessed 15 Aug 2011 (in Portuguese)

IDNR (2008) IDNR Division of Forestry strategic plan 2008-2013. Indiana Department of Natural Resources, Division of Forestry, Brownstown. http://www.in.gov/dnr/forestry/files/fo-ForestryStrategic-Plan-2008-2013.Final.pdf. Accessed 11 Oct 2010

Instituto Florestal (2010) SiFESP: Sistema de informações florestais do estado de São Paulo. http://www.iflorestal.sp.gov.br/sifesp/. Accessed 14 Aug 2011 (in Portuguese) 
Janota JJ, Broussard SR (2008) Examining private forest policy preferences. For Policy Econ 10(3):89-97

Jha S (2010) The struggle for democratizing forests: the forest rights movement in North Bengal, India. Soc Mov Stud 9(4):469-474

Jodha NS (1992) Common property resources: a missing dimension of development strategies. The World Bank, Washington, DC

Joly CA, Aidar MPM, Klink CA, McGrath DG, Moreira AG, Moutinho P, Nepstad DC, Oliveira AA, Pott A, Rodal MJN, Sampaio EVSB (1999) Evolution of the Brazilian phytogeography classification systems: implications for biodiversity conservation. Ciência e Cultura 51(5/6):331-347

Karppinen H (1998) Values and objectives of non-industrial private forest owners in Finland. Silva Fenn 32(1):43-59

Kauneckis D, York A (2009) An empirical evaluation of private landowner participation in voluntary forest conservation programs. J Environ Manage 44(3):468-484

Kilgore MA, Greene JL, Jacobson MG, Straka TJ, Daniels SE (2007) The influence of financial incentive programs in promoting sustainable forestry on the nation's family forests. J For 195(4):184-191

Kilgore MA, Snyder S, Taff S, Schertz J (2008) Family forest stewardship: do owners need a financial incentive? J For 106:357-362

Kindstrand C, Norman J, Boman M, Mattsson L (2008) Attitudes towards various forest functions: a comparison between private forest owners and forest officers. Scand J For Res 23(2): $133-136$

Knoot TG, Rickenbach M (2011) Best management practices and timber harvesting: the role of social networks in shaping landowner decisions. Scand J For Res 26(2):171-182

Knoot TG, Schulte LA, Rickenbach M (2010) Oak conservation and restoration on private forestlands: negotiating a social-ecological landscape. Environ Manage 45(1):155-164

Koontz TM (2001) Money talks—but to whom? Financial versus nonmonetary motivations in land use decisions. Soc Nat Resour 14:51-65

Korhonen K, Hujala T, Kurttila M (2012) Reaching forest owners through their social networks in timber sales. Scand J For Res 27(1):88-99

Lambin EF, Meyfroidt P (2010) Land use transitions: socio-ecological feedback versus socioeconomic change. Land Use Policy 27(2):108-118

Larson AM, Soto F (2008) Decentralization of natural resource governance regimes. Annu Rev Environ Resour 33(1):213-239

Laurance WF, Abernz AKM, Schroth G, Fearnside PM, Bergen S, Venticinque EM, Da Costa C (2002) Predictors of deforestation in the Brazilian Amazon. J Biogeogr 29:737-748

Liu J, Linderman M, Ouyang Z, An L, Yang J, Zhang H (2001) Ecological degradation in protected areas: the case of Wolong Nature Reserve for giant pandas. Science 292:98-101

Madison JH (1986) The Indiana way: a state history. Indiana University Press, Bloomington

Malingreau JP, Tucker CJ (1988) Large-scale deforestation in the southeastern Amazon Basin of Brazil. Ambio 17(1):49-55

Mansfield B, Munroe DK, McSweeney K (2010) Does economic growth cause environmental recovery? Geographical explanations of forest regrowth. Geogr Compass 4(5):416-427

Mather AS (1992) The forest transition. Area 24(4):367-379

McCay BJ, Acheson JM (eds) (1987) The question of the commons: the culture and ecology of communal resources. University of Arizona Press, Tucson

McGinnis MD (2011) An introduction to IAD and the language of the Ostrom Workshop: a simple guide to a complex framework. Policy Stud J 29(1):169-183

McKean MA, Ostrom E (1995) Common property regimes in the forest: just a relic from the past? Unasylva 46(1):3-15

McKibben B (2006) The end of nature. Random House, New York

MEA (2005) Millennium ecosystem assessment. http://www.millenniumassessment.org/en/index. aspx. Accessed 13 March 2013 
Meyfroidt P, Lambin EF (2009) Forest transition in Vietnam and displacement of deforestation abroad. Proc Natl Acad Sci U S A 106(38):16139-16144

Michalski F, Metzger JP, Peres CA (2010) Rural property size drives patterns of upland and riparian forest retention in a tropical deforestation frontier. Glob Environ Change 20(4):705-712

Moran EF (1992) Deforestation in the Brazilian Amazon. Indiana University Press, Bloomington

Moran EF (2010) Environmental social science: human-environment interactions and sustainability. Wiley-Blackwell, Sussex, UK

Moran EF, Ostrom E (eds) (2005) Seeing the forest and the trees: human-environment interactions in forest ecosystems. MIT Press, Cambridge

Moran EF, Packer A, Brondizio E, Tucker J (1996) Restoration of vegetation cover in the eastern Amazon. Ecol Econ 18:41-54

Moran EF, Brondizio ES, Tucker J, Silva-Forsberg MC, Falesi IC, McCracken S (2000) Strategies for Amazonian forest restoration: evidence for afforestation in five regions of the Brazilian Amazon. In: Hall A (ed) Amazonia at the crossroads: the challenge of sustainable development. Institute of Latin American Studies, London, pp 129-149

Murali KS, Murthy IK, Ravindranath NH (2006) Sustainable community forest management systems: a study on community forest management and joint forest management institutions from India. Int Rev Environ Strategies 6(1):23-39

Mutersbaugh T (2005) Just-in-space: certified rural products, labor of quality, and regulatory spaces. J Rural Stud 21:389-402

Mutersbaugh T, Klooster DK, Renard MC, Taylor PJ (2005) Certifying rural spaces: qualitycertified products and rural governance. J Rural Stud 21:381-388

Myers N, Mittermeier RA, Mittermeier CG, Fonseca GAB, Kent J (2000) Biodiversity hotspots for conservation priorities. Nature 403:853-858

Nagendra H (2007) Drivers of reforestation in human-dominated forests. Proc Natl Acad Sci U S A 104(39):15218-15223

Nagendra H, Pareeth S, Sharma B, Schweik CM, Adhikari KR (2008) Forest fragmentation and regrowth in an institutional mosaic of community, government and private ownership in Nepal. Landsc Ecol 23:41-54

Nagubadi V, McNamara KT, Hoover WL, Mills WL Jr (1996) Program participation behavior of nonindustrial private landowners: a probit analysis. J Agric Appl Econ 28(2):323-336

Nilsson S, Schopfhauser W (1995) The carbon-sequestration potential of a global afforestation program. Clim Change 30:267-293

Oestreicher JS, Benessaiah K, Ruiz-Jaen MC, Sloan S, Turner K, Pelletier J, Guay B, Clark KE, Roche DG, Meiners M, Potvin C (2009) Avoiding deforestation in Panamanian protected areas: an analysis of protection effectiveness and implications for reducing emissions from deforestation and forest degradation. Glob Environ Change 19(2):279-291

Ostrom E (1990) Governing the commons. Cambridge University Press, Cambridge

Ostrom E (2005) Understanding institutional diversity. Princeton University Press, Princeton

Ostrom E, Dietz T, Dolšak N, Stern PC, Stonich S, Weber EU (eds) (2002) The drama of the commons. National Academies Press, Washington, DC

Ostrom E, Janssen MA, Anderies JM (2007) Going beyond panaceas. Proc Natl Acad Sci U S A 104(39):15176-15178

Parker GR (1997) The wave of settlement. In: Jackson MT (ed) The natural heritage of Indiana. Indiana University Press, Bloomington, pp 369-381

Pelli P, Tikkanen I, Van Brusselen J, Vilén T, Weiss G, Tykkä S, Domínguez G, Boglio D, Kenter M (2009) Mid-term evaluation of the implementation of the EU Forest Action Plan. A study for the DG Agriculture and Rural Development. AGRI-2008-EVAL-07. European Commission, Brussels

Persha L, Blomley T (2009) Management decentralization and montane forest conditions in Tanzania. Conserv Biol 23(6):1485-1496

Polanyi K (1944) The great transformation: the political and economic origins of our time. Rinehart, New York 
Purbawiyatna A, Simula M (2008) Developing forest certification: towards increasing the comparability and acceptance of forestry certification systems worldwide. ITTO Tech Series \#29. International Tropical Timber Organization, Yokohama

Repetto R, Gillis M (eds) (1988) Public policies and the misuse of forest resources. Cambridge University Press, Cambridge

Ribeiro MC, Metzger JP, Martensen AC, Ponzoni FJ, Hirota MM (2009) The Brazilian Atlantic forest: how much is left, and how is the remaining forest distributed? Implications for conservation. Biol Conserv 142:1141-1153

Ribot JC (1999) Decentralisation, participation and accountability in Sahelian forestry: legal instruments of political-administrative control. Africa 69(1):23-64

Rickenbach M, Kittredge DB (2009) Time and distance: comparing motivations among forest landowners in New England, USA. Small Scale For 8:95-108

Rickenbach M, Schulte LA, Kittredge DB, Labich WG, Shinneman DJ (2011) Cross-boundary cooperation: a mechanism for sustaining ecosystem services from private lands. J Soil Water Conserv 66(4):91A-96A

Rosendal GK, Andresen S (2011) Institutional design for improved forest governance through REDD: lessons from the global environment facility. Ecol Econ 70(11):1908-1915

Ross-Davis AL, Broussard SR, Jacobs DF, Davis AS (2005) Afforestation motivations of private landowners: an examination of hardwood tree plantings in Indiana. North J Appl For 22:149-153

Rudel TK (1998) Is there a forest transition? Deforestation, reforestation, and development. Rural Sociol 63(4):533-552

Rudel TK (2002) Paths of destruction and regeneration: globalization and forests in the tropics. Rural Sociol 67(4):622-636

Rudel TK (2005) Tropical forests: regional paths of destruction and regeneration in the late twentieth century. Columbia University Press, New York

Rudel TK, Fu C (1996) A requiem for the southern regionalists: reforestation in the South and the uses of regional social science. Soc Sci Q 77(4):804-820

Rudel TK, Coomes OT, Moran EF, Achard F, Angelsen A, Xu J, Lambin E (2005) Forest transitions: towards a global understanding of the land use change. Glob Environ Change 15:23-31

Ruseva T, Fischer BC (2013) Public-private interactions in the conservation of private forests in the United States. In: Brondizio ES, Moran EF (eds) Human-environment interactions: current and future directions. Springer, Newark, pp 141-164

Schwartzman S, Nepstad D, Moreira A (2000) Arguing tropical forest conservation: people versus parks. Conserv Biol 14(5):1370-1374

Schweik CM, Nagendra H, Sinha DR (2003) Using satellite imagery to locate innovative forest management practices in Nepal. Ambio 32(4):312-319

SEADE (2011) Atlas SEADE da economia paulista. Fundação Sistema Estadual de Análise de Dados. http://www.seade.gov.br/produtos/atlasecon/. Accessed 14 Aug 2011 (in Portuguese)

Singh NM (2002) Federations of community forest management groups in Orissa: crafting new institutions to assert local rights. For Trees People Newsl 46:35-45

Smith WB, Miles PD, Perry CH, Pugh SA (2009) Forest resources of the United States, 2007. General technical report WO-78. USDA Forest Service, Washington, DC. http://www. treesearch.fs.fed.us/pubs/17334. Accessed 8 May 2012

Streightoff FD, Streightoff FH (1916) Indiana: a social and economic survey. Stewart, Indianapolis

Stuart A (1962) Basic ideas of scientific sampling. Charles Griffin, London

Sweeney SP, Evans TP (2012) An edge-oriented approach to thematic map error assessment. Geocarto Int 27(1):31-56

Terborgh J (1999) Requiem for nature. Island Press, Washington

Thompson MC, Baruah M, Carr ER (2011) Seeing REDD+ as a project of environmental governance. Environ Sci Policy 14(2):100-110

Tucker CM (2004) Community institutions and forest management in Mexico's Monarch Butterfly Reserve. Soc Nat Resour 17:569-587 
Tucker CM (2010) Learning on governance in forest ecosystems: lessons from recent research. Int J Commons 4(2):687-706

Tucker CM, Southworth J (2005) Processes of forest change at the local and landscape levels in Honduras and Guatemala. In: Moran EF, Ostrom E (eds) Seeing the forest and the trees: human-environment interactions in forest ecosystems. MIT Press, Cambridge, pp 253-277

Van Laerhoven F (2010) Governing community forests and the challenge of solving two-level collective action dilemmas-a large-N perspective. Glob Environ Change 20(3):539-546

VanWey LK, Ostrom E, Meretsky V (2005) Theories underlying the study of human-environment interactions. In: Moran EF, Ostrom E (eds) Seeing the forests and the trees: human-environment interactions in forest ecosystems. MIT Press, Cambridge, pp 23-56

Verhoeven H (2011) Climate change, conflict and development in Sudan: global neo-Malthusian narratives and local power struggles. Dev Change 42(3):679-707

Victor MAM, Cavalli AC, Guillaumon JR, Serra-Filho R (2005) Cem anos de devastação: revisitada 30 anos depois. Ministério do Meio Ambiente/Secretaria de Biodiversidade e Florestas, Brasília

Vokoun M, Amacher GS, Sullivan J, Wear D (2010) Examining incentives for adjacent nonindustrial private forest landowners to cooperate. For Policy Econ 12(2):104-110

Walker R (1993) Deforestation and economic development. Can J Reg Sci 16(3):481-497

Walker R (2012) The scale of forest transition: Amazonia and the Atlantic forests of Brazil. Appl Geogr 32:12-20

Winkel G, Sotirov M (2011) An obituary for national forest programmes? Analyzing and learning from the strategic use of "new modes of governance" in Germany and Bulgaria. For Policy Econ 13(2):143-154

Woodall CW, Johnson D, Gallion J, Perry C, Butler B, Piva R, Jepsen E, Nowak D, Marshall P (2005) Indiana's forests, 1999-2003 Part A. Resource bulletin NC-253A. USDA Forest Service, North Central Research Station, St Paul

Xavier AF, Leite SA (2008) Situação florestal/forest diagnosis. Florestar Estatístico 11(20): $56-81$

Young Z (2010) Strategies for effective and just conservation: the global environmental facility and India eco-development—growing the inefficient economic approach to conservation. Curr Conserv 3(3):27-30

Zanchi G, Thiel D, Green T, Lindner M (2007) Forest area change and afforestation in Europe: critical analysis of available data and relevance for international environmental policies. European Forest Institute, Joensuu

Zhang P, Shao G, Zhao G, Le Master DC, Parker GR, Dunning JB Jr, Li Q (2000) China's forest policy for the 21st century. Science 288(5474):2135-2136 